\title{
CORRIGENDUM Let's talk about class: towards an institutionalist typology of class relations in the cities of pre-modern Europe (c. I 200 - c. I800) - CORRIGENDUM
}

\author{
JEFF FYNN-PAUL \\ doi:10.1017/S0963926813001028. Published online by Cambridge University \\ Press, 10 January 2014
}

The editors regret that the title of the work cited on page 12 footnote 35 is incorrect. ${ }^{1}$ It should read: 'This material will be presented most fully in: J. Fynn-Paul, The Rise and Decline of an Iberian Bourgeoisie: Manresa in the Later Middle Ages (Cambridge, forthcoming)'.

\section{Reference}

${ }^{1} \mathrm{~J}$. Fynn-Paul, 'Let's talk about class: towards an institutionalist typology of class relations in the cities of pre-modern Europe (c. $1200-c .1800)^{\prime}$,' Urban History, published online 10 January, doi:10.1017/S0963926813001028. 